\title{
A New Confindustria For a NeW Model of Italian CAPitalism?
}

\author{
Vincent Della Sala
}

Among the scenarios raised by a more interdependent and open global economy is one of competition unleashed not only between states and firms, but also between national systems of corporate finance and governance. Less than a decade since the specter of a competition of capitalism against capitalism, the start of the new decade has seen a widespread belief that the Anglo-Saxon model of capitalism, with its emphasis on equity markets and shareholder rights, is the basis for convergence amongst advanced industrialized societies. ${ }^{1}$ More specifically, many argue that Italy has not escaped this discussion, and the past year has been one rich in developments that raise questions about the possible changing nature of the Italian model of capitalism. It is not unfair to ask whether Italy is moving towards a convergence with the AngloAmerican model of capitalism. The election of Antonio D'Amato as the new president of Confindustria might provide some insight into the extent of change in the Italian model of capitalism.

The chapter will argue that while Italian capitalism has undergone a number of important changes in recent years that have moved it closer to the Anglo-American model, it is premature to speak of convergence. The changes to Italian finance have led to a discussion of creating a shareholder and equity culture that challenges the almost oligarchic position of the salotto buono. Moreover, the move to more market-based forms of finance means that 
the strategic role of some banks and the state in shaping Italian economic activity may be reduced; and that power may now be shifting to individual and institutional investors, who may or may not be found in Italy. The chapter will argue that while there are many pressures for change, there has yet to be a rupture in the Italian model of capitalism. The new Confindustria leadership has begun to show a marked change in style that suggests a move in the direction of an Anglo-American model of capitalism. While the rhetoric towards government and the trade unions may be more confrontational, the basic structures of Italian capitalism are proving to be adaptable and resilient to the forces of change.

\section{The Italian Model of Capitalism}

It has become conventional wisdom that globalization creates pressures to give greater space to market forces for the allocation of resources. ${ }^{2}$ This implies that two of the essential features of models of capitalism - the relationship between finance and industry, and industrial relations - may be transformed. More specifically, the argument claims that capital is now free of most obstacles to seek out its highest returns. This will lead to greater efficiency, as more competition will drive down the cost of capital for industry; and will lead to a greater emphasis on market-based finance rather than that mediated through financial institutions such as banks, or perhaps even the state. ${ }^{3}$ There is, then, a shift from trying to accommodate the interests of various stakeholders to increasing shareholder value. ${ }^{4}$

There has been an array of alternative models that have conceptualized varieties of capitalism. ${ }^{5}$ For the sake of simplicity we can speak of "insider", or stakeholder, and "outsider", or shareholder, models in Europe. The first refers to systems such as Germany where a large role is given to banks in corporate finance, and corporatist-like arrangements govern capital-labor relations. It also includes examples such as France, where the state has played an important role, either through nationalized industries or public banks, in shaping corporate finance. These systems tend to have a close relationship between owners and managers, with corporate ownership tending to be characterized by concentration and cross-ownership of firms and/or banks. The second model, usually referred to as the Anglo-Saxon model, and said to characterize the United Kingdom and the United States, tends to have diffused ownership and a more anonymous relationship between owners (shareholders) and managers. While there may be some 
concern with other stakeholders in the firm, corporate interests and profit maximization for shareholders are paramount. The Italian model has always escaped easy classification but it has had essential elements of the "insider" model found in Germany and France. ${ }^{6}$ Italian capitalism in the postwar era was characterized by a very close relationship between the owners and managers, in both the public and private sectors; and that corporate finance was secured more through personal relations than through anonymous equity markets. ${ }^{7}$

The Italian model of capitalism has proven to be resilient and adaptable. However, by the end of the 1990s, many commentators in Italy and abroad felt that change was underway. The influential American magazine, Business Week, claimed that, "The country that was once the bastion of old-style capitalism in Europe is suddenly and spectacularly the Continent's most open economy." 8 What fueled this kind of optimism were not only the obvious examples of the hostile takeover of Telecom Italia by Olivetti, but also major mergers in the banking sector between Banca Intesa and BCI, and between Sao Paolo and IMI. The regulatory changes introduced in the late 1990s to protect small shareholders, combined with the decreased appeal of treasury bills as interest rates dropped and the slow move to introduce pension funds seemed to bring many more Italians into equity markets.

Surveys of household financial assets by the Bank of Italy in 1995 and 1998 indicate that there may be changes taking place on how Italians invest their money. There has been a move away from those instruments that are sensitive to interest rate changes (deposits and government securities). For instance, at the end of 1998, 11.8 percent of households held government securities, which was a drop from 26.4 percent at the end of 1995 . In contrast, 20.3 percent held mutual funds or shares at the end of 1998, while only 10.9 percent did so three years earlier. ${ }^{9}$ The rise in the percentage of individual household savings linked to equity markets - mutual funds and shares - was dramatic between 1990 and 1999, and especially since 1997 . For instance, they rose from 22.5 percent of household financial assets in 1990 to 34.3 percent in 1997 and to 49.3 percent in $1999 .{ }^{10}$ It means that a significant part of Italian savings are exposed to higher levels of risk, and this more likely to lead their holders to favor government policies that result in lower interest rates and affect profit levels of firms.

The Milan stock exchange also has shown signs of changes in the direction of the Anglo-Saxon model. The Borsa was often seen as being too small and cumbersome to provide access to cheap, readily available capital. ${ }^{11}$ Its privatization in the late 1990s was 
seen as an important step to stem the tide of Italian firms listing on overseas markets, especially London and New York. Regulations were changed so that firms no longer have to provide financial statements showing three consecutive years of profits before being able to list on the Borsa. The evidence seems to suggest that these changes, along with the moves to direct savings to equity markets, have led to an increase in the number of firms, listing and market capitalization. For instance, in 1975 there were 154 firms quoted on the exchange. The figure remained fairly stable for a decade, when there was a dramatic increase from 161 in 1985 to 201 firms in 1986. The figure continued to grow slowly in the period, and since then has leveled off at around 238 found in mid-2000. A more noticeable, and perhaps more important change, has been in the level of market capitalization. In 1975, the amount of capital available on the Borsa represented only 5.4 percent of GDP; again, the significant increase occurred in 1985 when it nearly doubled the previous year's figure to jump to 12.1 percent. It gradually increased to 20.2 percent in 1996. But it is in the period since then that the increases have been significant as the amount of capital increased by half in consecutive years so that by 1998 it was at 45 percent. It jumped again to 65.0 in 1999 and then reached 71.1 percent in August 2000.12

\section{A Year of Change?}

The year 2000 was rich with developments that, at the very least, introduced a number of new actors on the Italian stage. The changes that suggest a growing importance of equity markets have combined with a number of high profile hostile takeover bids and IPOs to fuel the belief that the "mold" of Italian capitalism had been broken. For instance, the reorganization of the banking sector continued with the agreement of a merger of Banca Intesa and Comit; Generali also strengthened its ties with Commerzbank, and extended its diversification as a financial services provider and not just insurance. More importantly, symbols of the Italian model, such as FIAT, Mediobanca and IRI underwent changes in 2000.

The year was not yet three months old when the news broke that FIAT had finally concluded its long awaited strategic alliance with a foreign partner. The choice of an American partner, rather than a European automobile manufacturer, was not entirely a surprise as there had been rumors that FIAT had been seeking a deal with Daimler-Chrysler, and possibly Ford. The terms of the agreement give GM a twenty per cent stake in FIAT Auto in return for a 
5.1 percent ownership in General Motors for the Torino firm. In addition, a joint venture will be launched to create a motor and spare parts division. There will be a "guiding committee" established to manage the joint venture as well as seek out new areas for co-operation, such as e-commerce, between the two partners. The alliance, given approval by the competition authorities of the European Union, will bring together two firms that have a combined share of 23 percent of the European market. An important part of the deal is that FIAT can exercise an option, between the third and ninth years of the accord, to have GM buy the remaining 80 percent of its automobile division. ${ }^{13}$

The importance of one of Italy's best-known and largest industrial firms seeking and concluding an alliance, and moreover with a foreign partner, was not lost on political and economic commentators. Massimo D'Alema expressed the government's support for the agreement and said, "L'economia italiana vive una fase di profonda trasformazione, che ha gia' cambiato e ancora di piu' in futuro cambiera' $i$ caratteri del capitalismo italiano." The alliance was part of a transformation that the government had supported and which would render Italian capitalism "meno asfittico e provinciale", and more open to change: essential conditions for a competitive economy. ${ }^{14}$ Support for the agreement also came from trade union circles, albeit after assurances that large job losses would not result from the new ownership structure. CGIL leader, Sergio Cofferati, re-affirmed D'Alema's claim that the changes to FIAT were a sign of a positive opening up of Italian capitalism; and represented the end of a corporate dynasty. ${ }^{15}$

While there was a chorus of voices that welcomed the introduction of a new player on to the Italian industrial landscape, it was not entirely clear that the agreement is a sign that Italy's "insider" model of capitalism had undergone a radical change. Gianni Agnelli, the titular if not real head of the FIAT empire, provided a hint that shareholder interests did not drive the deal. He claimed that the financial markets would have preferred that all of the auto division of FIAT be sold, and not just 20 percent. He also pointed out that, while GM retained the first option on the remaining 80 per cent, the remaining share would "never" be sold. In a different interview, he claimed that in addition to the shareholders the alliance took into consideration not just the shareholders but also all the stakeholders, from the citizens of Torino to FIAT's small suppliers and employees. ${ }^{16}$ This is hardly the sign of "pirate" or "casino" capitalism, driven by short-term interests of shareholders that is often ascribed to more market-based models of capitalism. More importantly, it was FIAT management that decided 
on the alliance, and not its shareholders. This seemingly watershed event in the history of Italian capitalism is not so clearly a sign that the "insider" model has given way to the power of financial and equity markets.

It was also a model of capitalism that had Enrico Cuccia and Mediobanca at its center. His death in June of the same year in which the Agnelli family loosened its ownership of FIAT inevitably led to speculation that an era had ended. Perhaps there are few figures that better embodied the essential features of the Italian model of capitalism than the legendary head of Mediobanca. The blurring of public and private, the complex network of cross-ownership to make it difficult for outsiders to gain control of firms, close ties between managers and owners of firms and the privileged position of a small ownership group over small shareholders were all captured by the complex web created by the enigmatic figure of Enrico Cuccia. ${ }^{17}$ There are few major industrial and financial ventures in postwar Italy that did not pass across his desk; even the Olivetti takeover of Telecom Italia, seen as the start of a new era for Italian capitalism, involved Mediobanca. The links between finance and industry in this model were a complex set of relationships that often had Cuccia and Mediobanca as its hub, and which often included achieving a balance between various political interests.

Given the nature of cross-holdings in Italian firms, the future of Mediobanca following Cuccia's death drew a great deal of attention; perhaps disproportionate to its size in comparison to some of the other firms which had their ownership in question. It was somewhat ironic that the major institution that guided a system that discouraged hostile take-over and corporate raids would be a possible target of the new rules of corporate finance. Cuccia understood this in the months before his death when he, as honorary chair, and Vincenzo Maranghi, the chief executive, concluded a series of agreements with allies that strengthened Mediobanca's defense against hostile take-over. ${ }^{18}$ These maneuvers continued after Cuccia's death and included increasing cross-holding stakes in Compart, Generali and Commerzbank. Part of the defense strategy also meant strengthening ties with some of the "noble wing" of the bank, and there were even rumors that Gianni Agnelli might be brought in as the new honorary chairman. It would seem, then, that the traditional position and way of doing business had returned to Mediobanca. However, much like the FIAT accord with $\mathrm{GM}$, it is an attempt to manage change in a more open environment by an institution that often worked in the closed and more secretive world of Italian capitalism. 
State capitalism was an important part of the Italian economy for most of the last century, with IRI at the center of the state's industrial and financial holdings. Its last scheduled annual general meeting was held on 28 July, with the major item on the agenda being the dissolution of the agency. The 1990s saw most of its holdings privatized or transferred to other agencies and departments; since 1992, over 90,000 billion IL in assets were sold. At the time of the July meeting, IRI still had a major stake in Cofiri, RAI, Fincantieri, Alitalia, and Tirrenia; and minor positions in Banca di Roma and Finmeccanica. ${ }^{19}$ These holdings would be transferred to the Treasury ministry that would eventually oversee their privatization. The agency had ceased to be a visible and central tool for industrial policy for some time. The commitment to close down IRI can be traced back to as early as 1993 with the agreement between Beniamino Andreatta and EU Commissioner Karl Van Miert to drastically reduce IRI's deficit and drain on public funds. This was followed up by Treasury Minister Ciampi's commitment in 1997 to close down IRI by 30 June 2000. Despite being a death foretold, the end of IRI did contain at least symbolic, if not financial and policy, importance. IRI had become a victim of political interference by the 1970 s and a constant charge on public finances, but its role in the economic boom in the 1950s and 1960s was instrumental for the development of Italian industry and capitalism.

However, the dissolution of IRI did not mean that state held agencies and firms did not play a prominent role in finance and industry during the year. For instance, while the promise of the liberalization of electrical power plants remained unrealized, ENEL pursued its policy of diversifying into new ventures. It concluded an agreement to buy Infostrada from the British-based Vodafone. The result was that the energy company owned Wind, the third largest mobile company (with France Telecom), and with its new acquisition, the second largest fixed-telephone service. The move led some to think that it was the sort of strategy reminiscent of IRI, as well as to speculate whether electricity customers were paying for the new acquisitions to the state-held company. ${ }^{20}$ Concerns about ENEL reflected a broader criticism that was leveled against the center-left governments; that is, while large amounts of the public sector had been privatized, the state retained an important presence in important parts of the Italian economy. For instance, charges for fixed telephone services are still set by the state regulators, leading to complaints that the demand by Telecom Italia for a rate increase was only designed to help its own expansion plans and finance the debt incurred for Olivetti's takeover eighteen months earlier. ${ }^{21}$ Utilities customers in Italy were caught in a strange 
form of cross-subsidization that did little to lower costs either for telephone or electricity services. It seemed that state capitalism (in the form of state-held firms such as ENEL and through regulation) was still in place, albeit in a modified form. The important difference is that there was no longer even the pretence or rhetoric of using it to achieve political and social objectives such as employment, regional development or generating finances for the state.

\section{A New Confindustria?}

There seemed to be a contrast, then, between an emerging capitalism that was more market-based, with a greater emphasis on equity markets and a looser connection between ownership and management, and the pillars of the postwar Italian capitalism seeking ways to adapt to a new environment. One way to see the extent to which this was leading to a change in the Italian model of capitalism is to examine closely developments in Confindustria. The past year had been an eventful one because it saw the election of a new leader, Antonio D'Amato, and a number of contentious issues that led to increased tensions with the government and trade unions.

The choice of Antonio D'Amato was presented as an important break with the past. At 43 years of age, the head of a family paper and packaging firm based in Napoli, he became the youngest head of Confindustria, and was closer in age to many members in its youth wing than to establishment figures such as Gianni Agnelli and Carlo De Benedetti. Moreover, he was also the first industrialist from the Mezzogiorno to lead the association so often associated with the industrial dynasties of northern Italy. D'Amato was the overwhelming choice, by a 96 to 58 margin, at the governing council meeting on 15 March, over Carlo Callieri, the candidate seen to be the favorite of the large industrial families of the North. ${ }^{22}$ Callieri, a vice-president with the association for eight years, had the support of the FIAT establishment, for whom he had worked, and other northern dynasties such as Pirelli and Marzotto. While the headlines proclaimed the victory a sign of a change in the balance of power in Italian capitalism, away from the large industrial concerns towards small and medium-sized and more geographically diffused firms, D’Amato also received support from important figures such as the Luciano Benetton and Cesare Romiti. Moreover, it was not the first time that the election of a new Confindustria president had created divisions between business leaders. It is interesting to note that the presumed candidate of the small and medium-sized enterprises, in his inaugural speech, pointed out that 
"small is not beautiful" in the global economy; and that the Italian model of capitalism did not produce enough firms that were major players on a global scale. The fact that Confindustria chose a young business leader from the south was important; but perhaps more important was his reputation for not hesitating to take controversial and strong positions on issues such as coordination, labor market flexibility and pension reform. It suggests more a change in style than substance.

D'Amato set out to give Confindustria a leaner, more rational structure at the center with greater powers to the territorial and functional bodies. In addition to redirecting more resources to the local level, the new structure will also have an enhanced European dimension in recognition of the importance of EU policies. His choice of vice-presidents reflects the delicate balance between the traditional bastions of Italian capitalism (Marco Tronchetti Provera from Pirelli) and emerging forces (Nicola Tognana, president of the Veneto industrialists). One other reform that has begun but is far from being completed is that of the selection procedure for the election of the president and the executive. The present system has three saggi (or sages) sound out the association's base for possible candidates, and present a list of nominees. Confindustria has over 170,000 firms, making it hard to devise a process whereby the selection committee might be able to construct a list of candidates that closely represents all of the membership. ${ }^{23}$ The present system also makes it easier for small powerful groups to exert influence far greater than their numbers within the association. The aim, then, is to find a manageable procedure that is more open and representative of the association,

D'Amato's program for the leadership emphasized a positive, offensive strategy to make increasing Italy's competitiveness a policy priority. The role of Confindustria was to push government and other social forces to untangle the "knots" that were obstacles to entrepreneurship. In his opening speech to the general assembly on 25 May, D'Amato made no effort to hide where he thought the roots of these obstacles were to be found. He described the world in which Italian firms operated as: "Una societa' atttraversata da frammentazioni, corporativismi, crescenti disuguaglianze. Un assetto istituzionale obsoleto. Un quadro politico instabile. Un sistema produttivo con trope contraddizioni. Un mondo del lavoro con troppe rigidita'." 24 D'Amato made it clear that the obstacles to the "modernization" of the Italian economy and society were "conservative" and "corporatist" vetoes that used their pivotal position to block changes in key areas such as labor market flexibility and pensions. It is easy to see why the trade union leaders, such as Ser- 
gio Cofferati of the CGIL, would react strongly to D'Amato's speech as the comment about "conservative" forces was aimed directly at them and their organizations. ${ }^{25}$

It is with the forceful approach to questions about "competitiveness" that we can begin to detect signs of change in Confindustria that reflect a broader development within Italian capitalism. This is not to say that the association and its members previously were not concerned with how they fared with respect to their corporate rivals, especially European, in the global economy. However, D'Amato suggested that business leaders in the past had taken a defensive approach to the issues at hand, and had refused to address serious structural problems. He accepted that coordination had played an important role in incomes policy in the 1990s, but argued that seeking accommodation with labor was only a means to competitiveness, and not an end in itself. ${ }^{26}$ It seems that D'Amato would like to see Italian employers begin to take an approach to labor along lines that are more similar to that in economies with Anglo-Saxon models of capitalism. The emphasis is on making their firms competitive, and on increasing profits, not on seeking ways to accommodate stakeholders. D'Amato argued that the search for accommodation, or at least the desire to avoid confrontation, meant that issues that were particularly important to compete in a global economy, such as labor market rigidity, were not addressed.

The word that underlies many of the contentious issues, and which reflects a greater emphasis on market forces emerging in Italian capitalism, is "flexibility". This is not just a rhetorical device adopted by the new Confindustria leadership, but a sign that the government and the social partners may now have to relate to each other on new terms. There was a whole range of issues where this new dynamic began to play itself out in 2000. The employers association kept up the pressure for the government to address the question of pension reform. However, given that the scheduled review of the 1995 Dini reforms is in 2001, this was mostly posturing for when the social partners and the government sit around the negotiating table.

A second issue related to pensions that gained attention during the year was the trattamento di fine rapporto (TFR), the severance payment fund to which all employers must contribute for each employee. It served a number of functions, especially for workers, for whom it was a form of forced savings. Employers had always seen the fund as a rather passive measure, with the funds a labor cost for them without any visible return. However, some did not hesitate to use them as a form of low-cost financing. ${ }^{27}$ The reform 
of the TFR was broached in the 1990s with the introduction of complementary pensions and pension funds in 1993. The Dini reforms allowed for workers in their first jobs to choose to put the TFR allocation into a pension fund; and for other workers to do so if their collective agreement had provided for it. Clearly, there was recognition that the TFR provided a large pool of capital, as much as 30-35,000 billion IL, that could be shifted to fund complementary pensions, and thereby relieve pressure on the state pension system. At the same time, it could help to establish pension funds as finance capital for Italian industry. The attraction for employers is not only that it might help reduce pension and labor costs, but also that the development of a significant pools of pension funds could help to reduce the overall cost of financing for business and industry. One other aspect that remains unsaid is that the TFR could be included in the labor market rigidity that D'Amato has said hurts Italian competitiveness; it adds to the cost of hiring and firing employees.

The D'Alema government brought to the Chamber of Deputies its plan for reform in February. While it received muted support from the trade unions, it met criticism from some of the government's own coalition members and Confindustria. The proposal, D.D.L. N.6787, would re-direct, for employees in both the private and public sectors, the employer contributions to the TFR to the pension funds set up for different occupational categories. In those cases where an occupational pension fund had not been established, employees could choose some other form of complementary pensions, as well as more open funds or even individual pension schemes. The proposal would also have firms lose control over the funds they had managed under the TFR. In return, their contributions to the general pension fund would be reduced as well as relief on other labor costs. The opposition to the measures could be found within the governing coalition, with the PPI ministers the most critical. ${ }^{28}$ They saw it as a lost opportunity to create more open financial markets, with an emphasis on individuals making choices about where to place their funds.

The criticism of "lost opportunity" was at the heart of the Confindustria opposition to the reform. The main problem for the employer association, as well as the other critics, was that the reforms seemed to favor the trade unions that would manage the "closed" occupational pension funds that would be the main destination for the former TFR allocations. Indeed, there were now even greater incentives for trade unions to establish and manage pension funds. Rather than introduce a new, more flexible instrument to capital markets, the proposals were seen as simply pro- 
viding a different form of the insider system that had characterized Italian finance and capitalism in the postwar period. It was felt that a system that would provide individual workers with greater scope to make decisions about where to place their funds was seen as one that favored capital markets much more than one that simply redirected funds from severance reserves to pools of capital managed by trade unions. ${ }^{29}$

What is particularly interesting in the Confindustria position on the reform of the TFR is the clear connection that is made between the reform of pensions and changing some of the basic structures of Italian capitalism. In addition to concerns about whether the proposals would lead to higher labor costs for employers, there was a discussion about how to use the funds as part of a broader strategy. All of the Confindustria leadership, even that under D’Amato's predecessor Giorgio Fossa, had argued that the reform of the TFR should not be an isolated event but part of a broader package of pension reform. More specifically, the emphasis is on moving to make individuals more directly responsible for their financial needs in retirement. This is consistent with a discussion of flexibility. It is easier for capital to move to investments that bring higher returns; it is easier for employers to hire and fire workers as the costs incurred will be reduced; and market operators, rather than the state or trade unions, will play an important role in managing savings and investments. Flexibility, it is argued, also results when individuals are free to manage their own retirement funds; that is, when they act as shareholders, and not stakeholders. However, the Confindustria leadership argued, the proposals put forward by the government would lead to a very different outcome. Rather than introduce flexibility to labor and financial markets, employers feared that a "closed" system that strengthened pension funds administered largely by trade unions would add rigidity to those markets. If the proposals were approved, it would be more difficult, in the discussion of pension reform scheduled for 2001, to put in place a more "flexible" pension regime that encouraged individuals to choose their pension options.

The Amato Government inherited the debate about the TFR reforms, and discussions continued through the autumn months. The new Confindustria leadership continued the association's opposition and sought to widen the discussion to include the seemingly unrelated issues of the underground economy, labor market flexibility and tax cuts. Sergio Cofferati, speaking on behalf of the CGIL, argued that the TFR issue had been resolved and could not understand why it should be part of the biannual discussions between the government and the social partners. However, the 
trade unions were divided on the question as both the UIL and CISL were in agreement with employers on having a broader agenda that included the reform of the TFR. ${ }^{30}$ It was clear that the issues being placed on the agenda were consistent with the Confindustria agenda of competitiveness and flexibility; and that D'Amato had succeeded in at least making them a policy priority for the Government.

D'Amato and the corporate leadership could begin to see signs that the policy agenda was beginning to tip in their favor. This was particularly evident with respect to taxation. ${ }^{31}$ Throughout the year, the government's economic ministers had pointed out that the aim was to reduce overall tax revenues, and to decrease income and corporate tax rates. The issue gained momentum in the autumn months with Confindustria calling for a radical approach to corporate taxation, and partially linking tax cuts to development policy for the South and bringing firms out from the underground economy. It presented a five-year plan to the government for cuts to the principal corporate tax, Irpeg. The first part of the plan would reduce the tax rates for firms that come out from the underground economy would have a tax rate of 1 percent in 2001, 15 percent in 2002 and 25 percent in 2003; and all firms in the south to have their rate drop from the present 37 percent to 25 in 2001. Firms in the rest of the country would enjoy the same decrease to 25 percent in the fifth year of the plan. ${ }^{32}$ The government replied with a modified six-year plan that would see firms that came out of the underground economy gradually reach the full corporate tax rate, which would drop from 37 to 35 percent.

It is not surprising that the CGIL opposed placing such a great emphasis on tax relief as a means of dealing with tax evasion and as a form of development policy for the south. Cofferati raised questions about how the decrease in revenues, projected to be 20,000 billion IL by the CGIL, would be recovered. He argued that the shortfall would have to be recovered by cuts to spending; while supporters of the plan argued that tax relief could have only a marginal effect on revenues as firms that had avoided taxes (and presumably their employees) would now be contributing to the state's coffers. What is perhaps more interesting is that the Confindustria plan was endorsed by Francesco Rutelli, the candidate selected to lead the Center-Left coalition in the elections in 2001. ${ }^{33}$ Perhaps this reflects the fact that the Center-Left trailed in the polls, and sought to remove tax relief as a platform for the Center-Right. However, it also may reflect the extent to which the Confindustria agenda of competitiveness and flexibility was in the ascendancy. The discussion about tax relief as a policy for regional development 
and employment is a clear sign that individuals and markets are to be agents of change and not the state.

It became clear over the course of the year that the balance of power between the social partners was changing, with the employers association beginning to be more aggressive and exploiting a political and economic environment different from the one that produced coordination in the 1990s. Unity in the labor movement, which had been elusive for most of the postwar period but was partly responsible for the coordination of the previous decade, began to fray. On a range of issues, the CGIL often found itself at odds not only with Confindustria, but also with the other trade union confederations. While Confindustria was selecting a leader with a reputation for not pulling back from confrontation, the trade unions found themselves on the defensive. For instance, they could take comfort in the fact that amongst the referenda that failed for lack of a quorum in May was one that would have abolished Article 18 of the Statuto dei Lavoratori. This provision binds employers to re-hire laid off workers before they can choose new employees. The issue was not dropped after the referendum failure, but was pressed by D'Amato and the Confindustria leadership. Enrico Morando, responsible for economic policy for the Democrats of the Left (DS), proposed that Article 18 not apply to firms with less than fifteen employees. Confindustria welcomed the proposal but felt that it did not go far enough; and wanted to have a broader debate about the question of how easy it will be for employers to hire and fire employees. ${ }^{34}$ It is clear that the issue is on the agenda and it is not likely that Confindustria will back down in the near future.

The government also was not spared its share of criticism. D’Amato's inaugural speech at the May general assembly severely criticized the government for its lack of initiative to tackle major structural problems. He even pointed out that the renewed health of public finances that allowed entry into the single currency was not the result of severe cuts to public spending but largely through tax increases. D'Amato's rebuke paled in comparison to Cesare Romiti's speech to the October meeting in Capri of the association's youth wing. Romiti claimed that the Center-Left government had exhausted its reason for being, and that it was best to have elections so that the process of serious structural reform to the economy could be renewed. Given that the speech was given at the time when most polls had the Center-Right well ahead of its rivals, it could have been seen as an endorsement of a change in government. D'Amato tried to calm the storm caused by the Romiti speech, and criticized both the Left and the Right for failing to 
bring about the structural reforms to give space to market forces in the economy. ${ }^{35}$ But the impression that Confindustria was comfortable in taking a more confrontational position with the government was not dispelled. Another sign of this was D'Amato's opposition to ENEL's membership in Confindustria; which led to the departure of Wind from the association, once it was taken over by the public electricity company. ${ }^{36}$

\section{Concluding Remarks: A New Confindustria for a New Italian Capitalism?}

The question that emerges from this discussion of the Confindustria agenda of competitiveness and flexibility, and a willingness to seek confrontation on it, is whether this is just a temporary phenomenon. Or, does it reflect a more fundamental change that stems from transformations in the Italian variety of capitalism? The dramatic increase in the capitalization of the Milan equity markets, and the gradual shift in Italian savings pattern, suggest that a small step has been taken towards creating shareholder capitalism in Italy. At the same time, the past year has seen some of the pillars of Italy's "insider" model of capitalism take steps to adjust to a more open economy. It might even be suggested that the nature of some major mergers in the past year have left even less room for small shareholders. ${ }^{37}$ Economic, like political, structures are slow to change and can prove to be adaptable, even to pressures that may come from the outside.

Yet, the discussion of Confindustria's campaign to emphasize competitiveness and flexibility, even if it means a confrontation with social partners, has elements of a different variety of capitalism. It also reveals some of the political consequences of moving towards a shareholder model of capitalism. First, it may mean that coordination, which produced important agreements on income policy, may be undermined by increasing tension between the social partners. Second, if the change in the savings habits of Italian households continues to evolve in the direction that it has since the mid-1990s, then they may begin to think of themselves more as shareholders than as stakeholders. Confindustria's plans to reform the TFR and pensions by making it easier for workers to make choices about their retirement savings would reinforce this trend. It would mean that developments in equity markets might be more important for the value of pensions than agreements reached between social partners. This could lead to a fundamental change in the balance of power between social partners; as well as differ- 
ent policy demands on governments. Trade unions and political parties may have to appeal to members and voters whose financial well-being, especially in retirement, is seen as tied to the performance of their equity portfolios, and not government policies. Moreover, it also may lead them to prefer to have more disposable income to place in those portfolios rather than contribute to social programs through taxation.

Italian capitalism is still far from being what might be characterized as being a shareholder model. Yet, it would seem that the new Confindustria leadership has understood that a move to shareholder capitalism may lead to a fundamental change in the political landscape. Its more aggressive and confrontational positions may be a sign not only of a change in tactics, but recognition that a new strategy may be more useful for a system that leaves less room for the accommodation of stakeholders' interests. The new model would not be without its problems for Confindustria. Indeed, it may be argued that the employers association is only trying to respond to, and possibly resist, pressures from changes in finance and the global economy. These could mean that control of many firms would no longer rest with Italians. Moreover, it does not say what will happen to the rich network of relationships that characterizes the terza Italia, where stakeholders are numerous and central to corporate decisionmaking. However, the past year has indeed given many signs that these issues have yet emerged as major concerns, and that the foundations of Italian capitalism have begun to change. It remains to be seen if they will crumble or adapt.

\section{Notes}

1. M. Albert, Capitalism against Capitalism, New York: Four Walls, Eight Windows Press, 1993.

2. C. Lane, "Globalization and the German Model of Capitalism - erosion or survival?," British Journal of Sociology, 51:2, June 2000, pp. 207-8.

3. R. Deeg and S. Perez, "International Capital Mobility and Domestic Institutions: Corporate Finance and Governance in Four European Cases," Governance, 13:2, April 2000, pp. 119-120.

4. D. Coates, Models of Capitalism: Growth and Stagnation in the Modern Era Cambridge: Polity Press, 2000, Ch. 1; L. Thurow, "Globalisation: The Product of a Knowledge Economy,” Annals, 570, July 2000, pp. 24-30.

5. M. Rhodes and B. van Appeldorn, "Capital Unbound? The transformation of European corporate governance," Journal of European Public Policy, 5:3 (Sep- 
tember 1998), pp .406-27; J. Story, “The Political Economy of European Union Financial Integration: The Battle of the Systems" in C. Crouch, ed. After the Euro: Shaping Institutions for Governance in the Wake of European Monetary Union, Oxford: Oxford University Press, 2000.

6. F. Barca, Impresa in Cerca di Padrone: Proprieta' a controllo nel capitalismo italiano, Bari: Laterza, 1994.

7. P. Bianchi, "Un capitalismo senza concentrazione," Il Mulino, XLI:2, MarchApril 1992, pp. 307-18.

8. “Commentary: Italy Breaks the Old Mold," Business Week (International Edition), 5 April 1999.

9. Source: Banca d'Italia, Supplementi al Bollettino Statistico - I bilanci delle famiglie italiane nell'anno 1995, March 1997, pp. 53-54; Banca d'Italia, Supplementi al Bollettino Statistico - I bilanci delle famiglie italiane nell'anno 1998, April 2000, pp. 63-64.

10. OECD, Economic Surveys - Italy 1999-2000, Paris:OECD, 2000, p.135.

11. R. Prodi, “Un modello strategico per le privatizzazion,i” Il Mulino, XLI:5, September-October 1992, pp. 851-852.

12. These figures may be found at: Borsa Italiana, Mercato in cifre, http://www. borsaitalia.it//4/200/202/573.html

13. “Alleanza Fiat-General Motors,” http://www.infosicilia.pa.it/lisoladelsole/lisoladelsole23/fiat.htm.

14. Interrogazioni a risposta immediate, n. 3-05295, 15 March 2000 at: http:// www.palazzochigi.it/approfondimenti/question_time150300.

15. M. Giannini, “Una svolta che fa bene all'economia italiana," La Repubblica, 13 March 2000.

16. F. Rampini, "Daimler bocciata perche' voleva tutto," La Repubblica, 14 March 2000.

17. G. Galli, Il Padrone dei Padroni: Enrico Cuccia, il potere di Mediobanca e il capitalismo italiano, Milano: Garzanti, 1995.

18. P. Betts, "Mediobanca on the menu," Financial Times, 5 September 2000, p. 16.

19. F. Bogo, "Il tramonto dell'Iri," La Repubblica, 26 June 2000,

20. F. M. Signoretti, "Amato: nessun peso sugli utenti, ma per il Polo e' statalizzazione," La Repubblica, 12 October 2000, p. 2.

21. F. Bonazzi, "I loro affair con I nostri soldi," L'Espresso - Online, 2 November 2000.

22. E. Imperiali, “Antonio D’Amato Nuovo Presidente Confindustria," Il Mattino, 16 March 2000.

23. V. Sivo, "D’Amato battezza la nuova Confindustria”, La Repubblica.11 October 2000, p. 43.

24. Confindustria, Assemblea Annuale - Relazione del Presidente Antonio D'Amato. Maggio, 2000.

25. F. Alvaro, “D’Amato all'attacco del sindacato," L'Unita, 26 May 2000, p. 3.

26. Antonio D’Amato, "Non romperemo con il sindacato", La Repubblica, 2 June 2000.

27. R. Romano, "Stato Sociale e Previdenza - Tra vincoli economici e diritti del lavoro” Cgil Ufficio Studi Lombardia, 3 February 2000, at: http://www.ecn.org/ coord.rsu/doc/altri2000.

28. R. Ippolito, “Seduta Turbolenta per il PPI," La Stampa, 5 February 2000, p. 3.

29. See Confindustria's submission to the Chamber of Deputies Labor Committee hearings on the government bill on 26 June 2000 at: http://www.confindustria. it/DBImages.nsf/HTMLPages/Informa. 
30. L. Palmerini, "Tfr - Si della Cisl a una trattiva complessiva anche su liquidazioni, sommerso e lavoro,” Il Sole 24 Ore, 13 October 2000, p. 8.

31. This view is shared by Cgil leader, Cofferati, in: Massimo Giannini, "Rutelli senza programma così rischia di naufragare,” La Repubblica, 6 November 2000, p. 9.

32. D. Pesole, "Parisi chiede che al Sud l'aliquota scenda al 25 percent nel 2001," Il Sole 24 Ore, 18 October 2000, p. 18.

33. R. Petrini, "Scontro Cofferati-Rutelli sull'Irpeg," La Repubblica, 3 November 2000. p .8.

34. F. Bullo, "Deroghe allo Statuto dei lavoratori per le aziende con meno di 15 dipendenti," La Stampa, 16 June 2000, p. 16.

35. V. Sivo, "D’Amato alza il tiro," La Repubblica, 7 October 2000, p. 4.

36. N. Natoli, "Wind-D’Amato a torte in faccia," Il Giorno, 26 September 2000, p. 13.

37. A. Devil, "Gli azionisti temono la politica perche' non conoscono I propri interessi,” L'Espresso Online, 2 November 2000. 